\title{
Prostate Cancer Pathologic Primary Tumor TNM Finding v7
}

National Cancer Institute

\section{Source}

National Cancer Institute. Prostate Cancer Pathologic Primary Tumor TNM Finding v7. NCI Thesaurus. Code C89201.

A pathologic finding about one or more characteristics of prostate cancer, following the rules of the TNM AJCC V7 classification system as they pertain to staging of the primary tumor. There is no pathologic T1 classification for prostate cancer. (from AJCC 7th Ed.) 